Check for updates

Cite this: RSC Adv., 2017, 7, 33052

\section{First synthesis of rugosaflavonoid and its derivatives and their activity against breast cancer $\dagger$}

\author{
Ninad V. Puranik (D) and Pratibha Srivastava (D)*
}

Rugosaflavonoid, is a secondary metabolite isolated from the plant Rosa rugosa was synthesized in five simple steps from commercially available 3,5-dihydroxy benzoic acid involving domino aldol-Michaeloxidation reaction. This is the first report of the synthesis of rugosaflavonoid (6a). A series of its derivatives were also synthesized, characterized and evaluated for the cytotoxicity against the breast cancer MCF-7 and normal NIH3T3 cell lines. The synthetic derivatives of rugosaflavonoid showed comparable activity in both the cell lines and compounds $6 \mathrm{~d}, 6 \mathrm{e}$ and $6 \mathrm{f}$, which were found to be cytotoxic towards MCF-7 cell lines but nontoxic to NIH3T3 cell lines at $5 \mu \mathrm{M}$ concentration. In an attempt to explore the mode of action of the best active compounds, docking on the ATP binding site of EGFR (1M17) was performed considering that EGFR over-expressed in most of the tumors. The docking score (Gscore) of $6 f$ and standard quercetin was found to be -8.608 and -8.310 respectively.

Received 3rd May 2017

Accepted 20th June 2017

DOI: 10.1039/c7ra04971d

rsc.li/rsc-advances

\section{Introduction}

Cancer still continues to be one of the major threats to human society because it is widely spreading day by day and there is no complete cure for it. The three most commonly diagnosed types of cancer among women in 2010 were cancers of the breast, lung, and colorectum, accounting for $52 \%$ of cancer cases in this group. Breast cancer (BC) represents the most common cancer among women; there were 232672 estimated new cases and 40000 estimated deaths in the United States in 2014. ${ }^{1-3}$ The toxicity allied with conventional cancer chemotherapy arises primarily from the lack of specificity for tumor cells. It leads to a low therapeutic index, which results in undesirable damage to healthy organs and consequently puts restrictions on the dose of the drug that can be administered. The majority of the currently available anticancer drugs are designed to have specific toxicity toward tumor cells. ${ }^{4,5}$ Several trials are being considered to handle this predicament and thus improve the effectiveness and tumor cell specificity of anticancer drugs. Among these approaches, many studies have focused on natural compounds that inhibit precisely the growth of cancer cells more selectively than normal cells. Thus, phytoconstituents have become the dignified category of anticancer drugs. Over $75 \%$ of non-biological anticancer drugs approved between 1981 and 2007 were either natural products or were developed based on them. ${ }^{6}$ Therefore, the search for new anticancer agents

Bioprospecting Group, Agharkar Research Institute, G. G. Agarkar Road, Pune, 411004, Maharashtra, India.E-mail: ninadv_puranik@yahoo.co.in; psrivastava@aripune.org $\dagger$ Electronic supplementary information (ESI) available. See DOI: 10.1039/c7ra04971d continues to draw attention to the research community. Nature is the biggest lab where millions of chemical reactions are taking place in milliseconds. Medicinal plants are one of the best equipment for the biosynthesis of various drug based molecules. Chromone is a valid scaffold ${ }^{7}$ in the field of medicinal chemistry, due to the wide range of its biological activities, and their structure-activity relationships have generated curiosity among medicinal chemists, and this has culminated into the breakthrough of the clinical anticancer agent flavopiridol, as well as several lead molecules in other disease areas. ${ }^{8}$ Rosa rugosa Thunb. belongs to the family of Rosaceae is a common ornamental flower distributed in the temperate regions of eastern Asia and widely cultivated in Yunnan Province. ${ }^{9}$ The petals and buds of $R$. rugosa are frequently used as food, incense, and Chinese medicinal materials for the cure of stomachache, diarrhea, and gynecological ailments..$^{10}$ The literature survey has shown the presence of tannins, terpenoids ${ }^{11-13}$ and flavonoids ${ }^{14,15}$ in this genus. Anti-inflammatory, cytotoxic and anti-HIV activities have observed with selected chemical ingredients isolated from $R$. rugosa.$^{16} \mathrm{Hu}$ et al. ${ }^{17}$ have recently isolated and characterized cytotoxic oxepinochromenone and flavonoids from $R$. rugosa. Rugosaflavonoid is a new flavonoid, isolated from Rosa rugosa which showed cytotoxicity against NB4, SHSY5Y, and MCF-7 cells. Till today the synthesis of rugosaflavonoid (Scheme 1) is not reported in the literature. Therefore, we have focused to synthesize recently isolated naturally occurring rugosaflavonoid (6a) and its derivatives by simple and convenient method. All the synthesized derivatives were evaluated for their cytotoxicity against the breast cancer cell lines MCF-7 and the normal cell lines NIH3T3. 


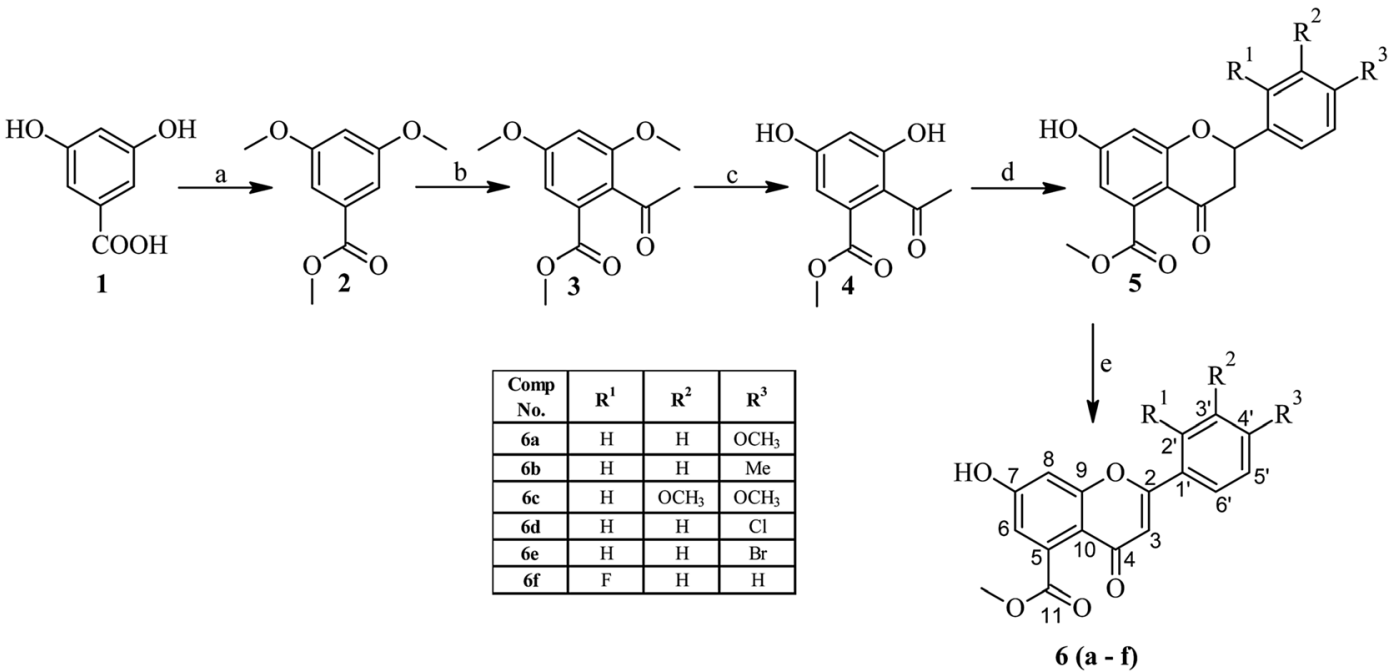

Scheme 1 Synthesis of rugosaflavonoid and its derivatives using 3,5-dihydroxybenzoic acid as starting material.

\section{Results and discussion}

The synthesis of rugosaflavonoid (6a) and its derivatives was accomplished in 5 simple steps by selecting 3,5-dihydroxybenzoic acid (1) as a building block (Scheme 1). In the first step 3,5dihydroxybenzoic acid was methylated using dimethyl sulfate in presence of the base, ${ }^{18}$ which produced methoxy ester (2) with $92 \%$ yield. The resultant ester was further acylated using acetyl chloride in carbon disulfide into methyl 2-acetyl-3,5dimethoxybenzoate (3) with $52 \%$ yield. ${ }^{19}$ Demethylation of methyl 2-acetyl-3,5-dimethoxybenzoate (3) using $\mathrm{BBr}_{3}$ in dichloromethane was attempted as per the procedure reported, ${ }^{\mathbf{2 0}}$ however, unfortunately only monomethylated product was obtained. Thus, $\mathrm{AlCl}_{3}$ was used ${ }^{21}$ instead of $\mathrm{BBr}_{3}$ to get the desired demethylated product in good yield. Attempt to cyclize intermediate methyl 2-acetyl-3,5-dihydroxybenzoate (4) to rugosaflavonoid (6a) by the literature method ${ }^{22}$ was unsuccessful, because the reaction resulted into the formation of methyl 7-hydroxy-2-(4methoxyphenyl)-4-oxo-3,4-dihydro- $2 H$-chromene-5-carboxylate (5) rather than rugosaflavonoid (6a), which was accentuated by

Table 1 Docking and cytotoxicity results of compound 6(a-j) showing cell viability analysis results after MTT assay against MCF-7 and NIH3T3 cell lines. Results are presented in \% cell viability. Four different concentrations $(5,10,15$ and $20 \mu \mathrm{M})$ of each compound were used for experiments $^{a}$

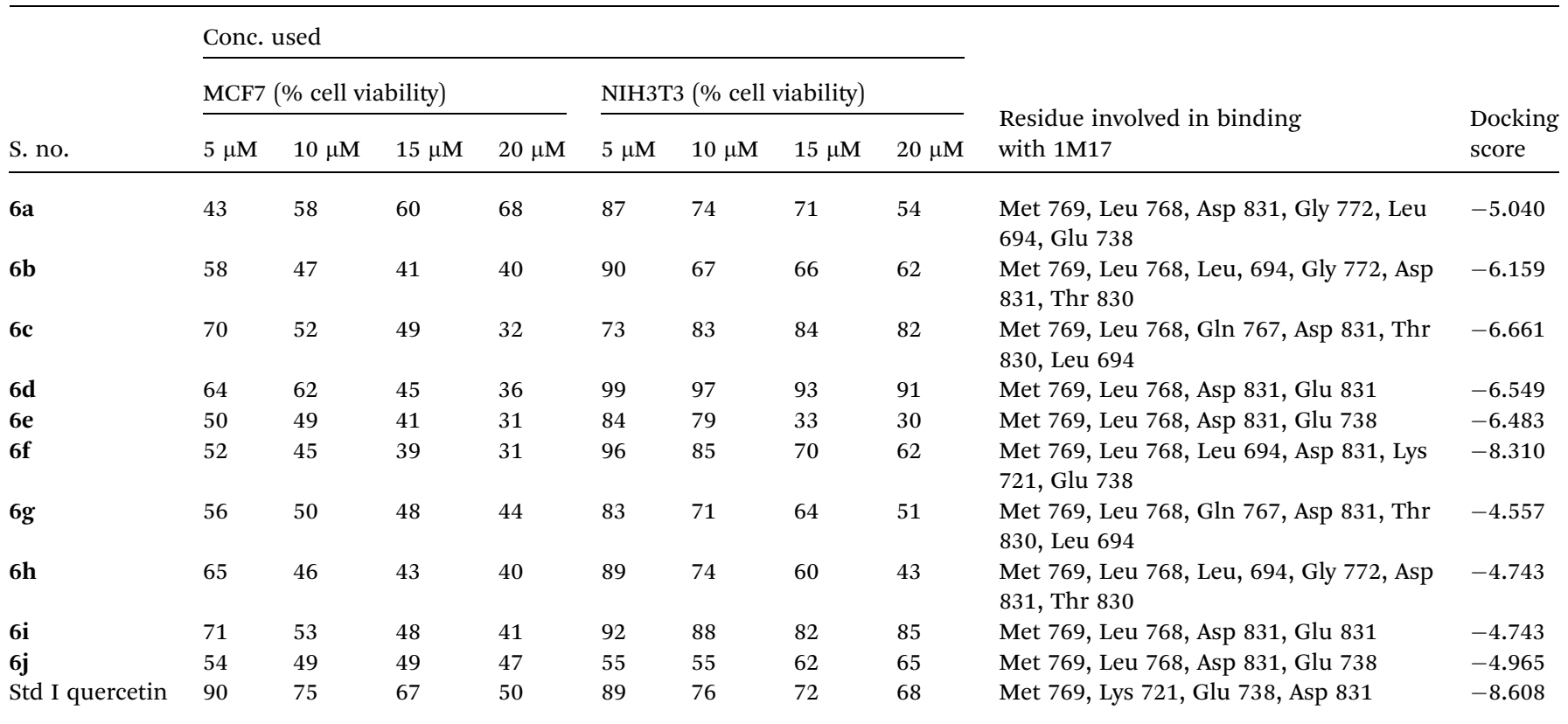

${ }^{a}$ All the samples run in triplicate and average of three results are presented here. 


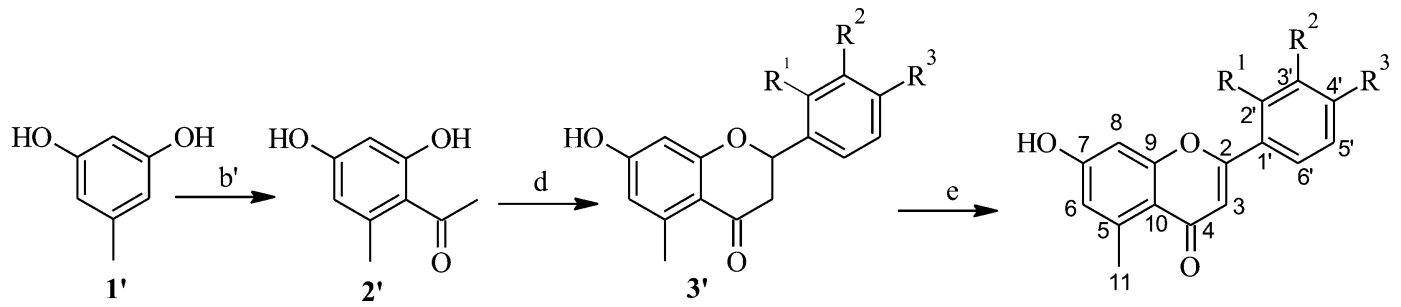

$6(g-j)$

\begin{tabular}{|c|c|c|c|}
\hline $\begin{array}{c}\text { Comp } \\
\text { No. }\end{array}$ & $\mathbf{R}^{\mathbf{1}}$ & $\mathbf{R}^{\mathbf{2}}$ & $\mathbf{R}^{\mathbf{3}}$ \\
\hline $\mathbf{6 g}$ & $\mathrm{H}$ & $\mathrm{H}$ & $\mathrm{OCH}_{3}$ \\
\hline $\mathbf{6 h}$ & $\mathrm{H}$ & $\mathrm{H}$ & $\mathrm{CH}_{3}$ \\
\hline $\mathbf{6 i}$ & $\mathrm{F}$ & $\mathrm{H}$ & $\mathrm{H}$ \\
\hline $\mathbf{6 j}$ & $\mathrm{H}$ & $\mathrm{OCH}_{3}$ & $\mathrm{OCH}_{3}$ \\
\hline
\end{tabular}

Scheme 2 Synthesis of rugosaflavonoid derivatives using orcinol as starting material.

spectral data. This reaction was attempted 3-4 times to get the required compound (6a), but it couldn't be obtained. Eventually, the final step was carried out using the intermediate 5 with $\mathrm{I}_{2}$ and DMSO (Scheme 1), which provided the desired product (6a) during 1 hour only. Rugosaflavonoid was obtained as a yellow solid. A molecular formula of $\mathrm{C}_{18} \mathrm{H}_{14} \mathrm{O}_{6}$ was confirmed by LC-MS $m / z 326.30\left[\mathrm{M}^{+}\right]$and HRMS $m / z 327.0853[\mathrm{M}+1]^{+}$. The ${ }^{1} \mathrm{H}$ NMR and ${ }^{13} \mathrm{C}$ NMR data of $6 \mathbf{a}$ were obtained and compared (Table 2) with the reported data $^{17}$ and were found in agreement with natural product rugosaflavonoid. It revealed that the compound 6a has 18 carbon and 14 protons. The ${ }^{1} \mathrm{H}$ NMR of $6 \mathbf{a}$ showed proton signals for methoxycarbonyl group $\delta(3.81, \mathrm{~s}, 3 \mathrm{H})$, a methoxy group $(3.86, \mathrm{~s}, 3 \mathrm{H})$, and other proton peaks at $\delta 6.79(\mathrm{~s}$, $1 \mathrm{H}, 3-\mathrm{H}), 6.82(\mathrm{~d}, 1 \mathrm{H}, 8-\mathrm{H}, J=1.6 \mathrm{~Hz}), 7.10(\mathrm{~d}, 1 \mathrm{H}, 6-\mathrm{H}, J=2 \mathrm{~Hz})$, 7.12 (d, 2H, 3' $5^{\prime}-\mathrm{H}, J=7.2 \mathrm{~Hz}$ ), 8.04 (d, 2H, 2', 6'- $\mathrm{H}, J=7.2 \mathrm{~Hz}$ ), and a phenolic hydroxylic proton at $11.14(\mathrm{~s}, 1 \mathrm{H}, \mathrm{OH})$. The ${ }^{13} \mathrm{C}$ NMR of compound 6 displayed carbon signals at $\delta 52.86(\mathrm{C}-11$, $\left.\mathrm{OCH}_{3}\right), 55.97\left(\mathrm{C}-4^{\prime}, \mathrm{OCH}_{3}\right), 104.25$ (C-8), 105.58 (C-3), 113.55 (C10), 113.94 (C-6), $114.81\left(\mathrm{C}-3^{\prime}\right), 114.98\left(\mathrm{C}-5^{\prime}\right), 123.49\left(\mathrm{C}-1^{\prime}\right)$,
$127.11\left(\mathrm{C}-6^{\prime}\right), 128.59$ (C-2'), 134.55 (C-5), 157.7 (C-9), $158.55\left(\mathrm{C}-4^{\prime}\right)$ 162.39 (C-2), 162.54 (C-7), 169.19 (C-11), 175.68 (C-4). The IR exhibited the peak at $3446(\mathrm{OH})$, and $1735(\mathrm{C}=\mathrm{O}), 1624(\mathrm{C}=\mathrm{O})$. Several derivatives of the rugosaflavonoid using different aromatic aldehydes were also synthesized. Hu et al. had reported ${ }^{17} 13.6 \mathrm{mg}$ of rugosaflavonoid (6a) from $8 \mathrm{~kg}$ of plant material after several steps of purification. But in the current experiment, $250 \mathrm{mg}$ rugosaflavonoid (6a) was obtained from $1 \mathrm{~g}$ of methyl 2-acetyl-3,5dihydroxybenzoate (4) via the intermediate 5 . The derivatives were also synthesized by replacing the ester group with the methyl group in rugosaflavonoid moiety. These derivatives were synthesized using orcinol ( $\left.\mathbf{1}^{\prime}\right)$ as a starting material (Scheme 2), which was acylated followed by the previously stated procedure of cyclization to yield the compounds $(\mathbf{6} \mathbf{g}-\mathbf{j})$. The rugosaflavonoid and its derivatives displayed comparative results in the MTT cytotoxicity assay. The details are presented in the Table 1 . The synthetic rugosaflavonoid (6a) showed 50\% cytotoxicity to MCF-7 cells at $5 \mu \mathrm{M}$ concentration, but its cytotoxicity reduced after enhancing concentration up to $20 \mu \mathrm{M}$ with $68 \%$ cell viability of

Table 2 Comparative data of synthesized and isolated rugosaflavonoid

\begin{tabular}{|c|c|c|}
\hline $\mathrm{Mp}$ & $226-228^{\circ} \mathrm{C}$ & Not reported \\
\hline HRMS & $\begin{array}{l}m / z 327.0863[\mathrm{M}+1]^{+}\left(\text {calcd for } \mathrm{C}_{18} \mathrm{H}_{15} \mathrm{O}_{6}\right. \\
327.0863)\end{array}$ & $\begin{array}{l}\text { HRESIMS } m / z 349.0682[\mathrm{M}+\mathrm{Na}]^{+} \text {(calcd for } \\
\mathrm{C}_{18} \mathrm{H}_{14} \mathrm{NaO}_{6}, 349.0688 \text { ) }\end{array}$ \\
\hline $\operatorname{IR}\left(\mathrm{cm}^{-1}\right)$ & $\begin{array}{l}3446,1735,1624,1600,1543,1436,1435,1253 \\
1180,1029,894\end{array}$ & $\begin{array}{l}3416,1702,1657,1610,1565,1456,1432,1287 \\
1182,1028,893\end{array}$ \\
\hline${ }^{1} \mathrm{H}$ NMR & $\begin{array}{l}\left(\text { Solvent DMSd }_{6}\right) \delta 3.81,\left(\mathrm{~s}, 3 \mathrm{H}, \mathrm{OCH}_{3}\right), 3.86(\mathrm{~s}, \\
\left.3 \mathrm{H}, \mathrm{OCH}_{3}\right), 6.79(\mathrm{~s}, 1 \mathrm{H}, 3-\mathrm{H}), 6.82(\mathrm{~d}, 1 \mathrm{H}, 8-\mathrm{H}, J= \\
1.6 \mathrm{~Hz}), 7.10(\mathrm{~d}, 1 \mathrm{H}, 6-\mathrm{H}, J=2 \mathrm{~Hz}), 7.12(\mathrm{~d}, 2 \mathrm{H}, \\
\left.3^{\prime}, 5^{\prime}-\mathrm{H}, J=7.2 \mathrm{~Hz}\right), 8.04\left(\mathrm{~d}, 2 \mathrm{H}, 2^{\prime}, 6^{\prime}-\mathrm{H}, J=7.2\right. \\
\mathrm{Hz}), 11.14(\mathrm{~s}, 1 \mathrm{H}, \mathrm{OH})\end{array}$ & $\begin{array}{l}\left.\text { (Solvent pyridine-d } \mathrm{d}_{5}, 500 \mathrm{MHz}\right) \delta 3.80(\mathrm{~s}, 3 \mathrm{H}, \\
\left.\mathrm{OCH}_{3}\right), 3.95\left(\mathrm{~s}, 3 \mathrm{H}, \mathrm{OCH}_{3}\right), 6.68(\mathrm{~s}, 1 \mathrm{H}, 3-\mathrm{H}), 6.74 \\
(\mathrm{~d}, 1 \mathrm{H}, 8-\mathrm{H}, J=1.8 \mathrm{~Hz}), 6.89(\mathrm{~d}, 1 \mathrm{H}, 6-\mathrm{H}, J=1.8 \\
\mathrm{Hz}), 7.00\left(\mathrm{~d}, 2 \mathrm{H}, 3^{\prime}, 5^{\prime}-\mathrm{H}, J=8.8 \mathrm{~Hz}\right), 7.76(\mathrm{~d}, 2 \mathrm{H}, \\
\left.2^{\prime}, 6^{\prime}-\mathrm{H}, J=8.8 \mathrm{~Hz}\right)\end{array}$ \\
\hline${ }^{13} \mathrm{C}$ NMR & $\begin{array}{l}52.86\left(\mathrm{OCH}_{3}\right), 55.97\left(\mathrm{C}-4^{\prime}, \mathrm{OCH}_{3}\right) 104.25(\mathrm{C}-8), \\
105.58(\mathrm{C}-3), 113.55(\mathrm{C}-10), 113.94(\mathrm{C}-6), 114.81 \\
\left(\mathrm{C}-3^{\prime}\right), 114.98\left(\mathrm{C}-5^{\prime}\right), 123.49\left(\mathrm{C}-1^{\prime}\right), 127.11\left(\mathrm{C}-6^{\prime}\right), \\
128.59\left(\mathrm{C}-2^{\prime}\right), 134.55(\mathrm{C}-5), 157.7(\mathrm{C}-9), 158.55(\mathrm{C}- \\
\left.4^{\prime}\right), 162.39(\mathrm{C}-2), 162.54(\mathrm{C}-7), 169.19(\mathrm{C}-11), \\
175.68(\mathrm{C}-4)\end{array}$ & $\begin{array}{l}52.4\left(\mathrm{OCH}_{3}\right), 55.6\left(\mathrm{C}-4^{\prime}, \mathrm{OCH}_{3}\right), 103.8(\mathrm{C}-8), \\
105.2(\mathrm{C}-3), 113.1(\mathrm{C}-6), 115.6\left(\mathrm{C}-3^{\prime}\right), 115.6\left(\mathrm{C}-5^{\prime}\right), \\
122.9\left(\mathrm{C}-1^{\prime}\right), 131.0\left(\mathrm{C}-2^{\prime}\right), 131.0\left(\mathrm{C}-6^{\prime}\right), 136.8(\mathrm{C}-5), \\
158.8(\mathrm{C}-9), 163.2(\mathrm{C}-2), 165.0(\mathrm{C}-7), 168.3(\mathrm{C}-11), \\
181.5(\mathrm{C}-4)\end{array}$ \\
\hline
\end{tabular}




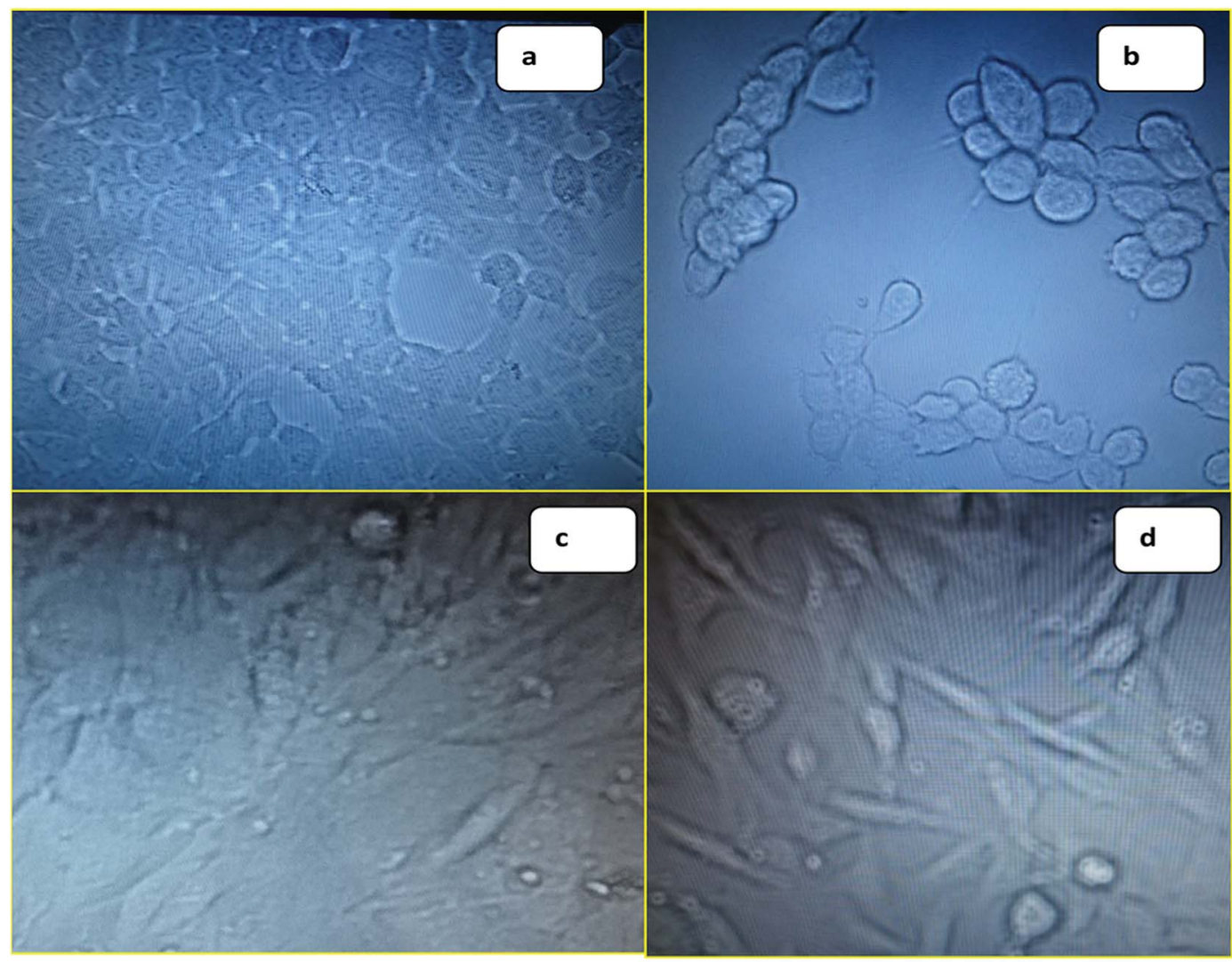

Fig. 1 (a) Image of MCF-7 before treatment with 6f; (b) image of MCF-7 after treatment with 6f; (c) image of NIH3T3 before treatment with 6f; (d) image of NIH3T3 after treatment with $6 \mathrm{f}$.

MCF-7 cells. It was found to be non-toxic to NIH3T3 normal cell line with $87 \%$ cell viability at the lower concentration of $5 \mu \mathrm{M}$. However, the toxicity increased with the higher concentration. The derivative $\mathbf{6 b}$ showed dose dependent cytotoxicity towards MCF-7 and NIH3T3 cell lines. Compounds 6c and 6i showed marginal cytotoxicity towards MCF-7 and NIH3T3 cell lines at lower concentrations, whereas they displayed high cytotoxicity at $20 \mu \mathrm{M}$ concentration. When the methoxy substituent at $4^{\prime}$ position of rugosaflavonoid was replaced with halogen, the compounds 6d, 6e and 6 f expressed 50\% cytotoxicity of MCF-7 cells at the lower concentration. The synthesized derivatives of rugosaflavonoid showed dose-dependent cytotoxicity on MCF-7 cell lines and most of them were non-toxic to NIH3T3 cells. The dimethoxy derivatives $\mathbf{6 c}$ and $\mathbf{6 j}$ showed inhibition of growth of MCF-7, but they were toxic to normal cells. The images of MCF-7 and NIH3T3 cells with 6 f before the treatment and after the treatment are shown in the Fig. 1.

The tyrosine kinase epidermal growth factor receptor (EGFR) is a transmembrane receptor central to numerous cellular process comprising cell migration, adhesion, apoptosis and cell proliferation. The EGFR is over-expressed in almost $90 \%$ of tumors. ${ }^{23,24}$ Protein-ligand interaction of 1M17 with EGFR-specific inhibitor ${ }^{25}$ and anticancer agent, erlotinib, demonstrated computationally that Met 769 formed hydrogen bond with tyrosine kinase inhibitor, whereas Leu 820, Leu 768,
Gly 772, Met 769, and Leu 694 indicated hydrophobic interaction with tyrosine kinase inhibitor, erlotinib. Therefore, interaction studies of rugosaflavonoid compounds were carried out with EGFR (1M17) and compared with the molecular docking of quercetin with 1M17. Interestingly, almost all the synthesized compounds showed non bonded interactions (Fig. 2) with the same residues such as Leu 768, Gly 772, Met 769 and Asp 831 as observed in the crystal structure of 1M17 with erlotinib. The protein-ligand interaction profile of $\mathbf{6 f}$ revealed that Lys 721, Glu 738, Met 769 and Asp 831, amino acids involved in the hydrogen bond and $\pi-\pi$ interactions in addition to hydrophobic interaction. Molecular docking score of quercetin and $6 \mathbf{f}$ with $1 \mathrm{M} 17$ were found to be -8.310 and -8.608 respectively. This result is in agreement with the data published by Singh and Bast. ${ }^{26}$ Overall, docking analysis of standard quercetin and rugosaflavonoid derivatives with 1M17 indicated that these derivatives had equal binding affinity which was also well noticed from experimental cytotoxicity results (Table 1).

\section{Experimental section}

\subsection{Materials and method}

All the chemicals used during the reactions were procured from Spectrochem, India. ${ }^{1} \mathrm{H}$ NMR and ${ }^{13} \mathrm{C}$ NMR spectra were 

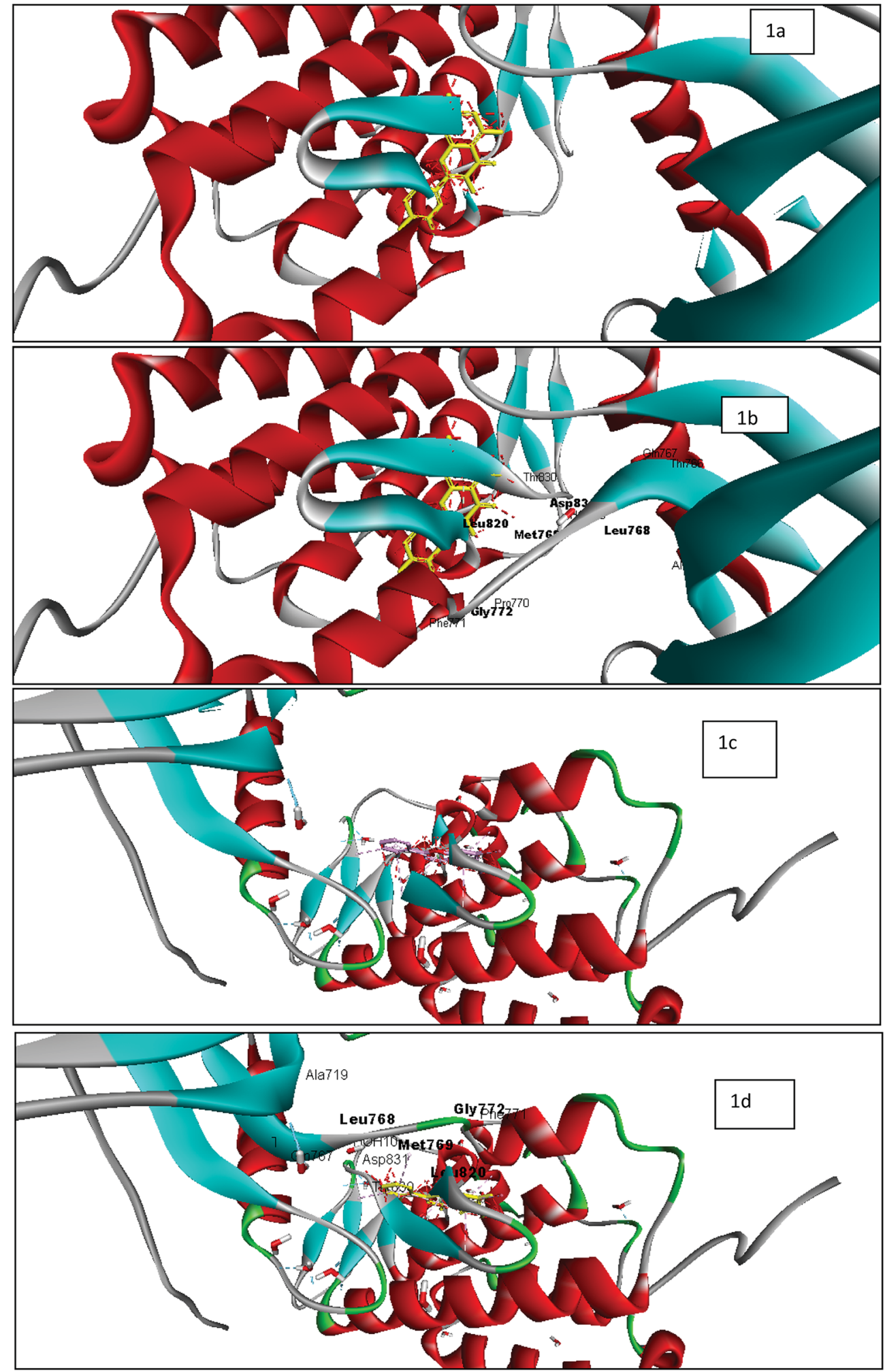

Fig. 2 Docking studies of rugosaflavonoid derivatives with EGFR (1M17) using discovery studio client version 4.0 (a) image of 1 M17 with quercetin without active site pocket; (b) image of $1 \mathrm{M} 17$ with quercetin with active site pocket (c) image of $1 \mathrm{M} 17$ with $6 \mathrm{f}$ without active site pocket; (d) image of $1 \mathrm{M} 17$ with $6 \mathrm{f}$ with active site pocket. 
recorded at the room temperature on Varian $400 \mathrm{MHz}$ spectrometer and $100 \mathrm{MHz}$ respectively. Chemical shift values were reported with reference to TMS as an internal standard. The samples were prepared by dissolving the synthesized compounds in DMSO- $\mathrm{d}_{6}$, chemical shifts were expressed in $\delta$ (ppm) and coupling constants $(J)$ in hertz. The splitting pattern abbreviations are as follows: s, singlet; $d$, doublet; $t$, triplet; q, quartet; m, unresolved multiplet; dd, doublet of doublet. The column chromatography was performed on Merck silica gel 60 (230-400 mesh). Analytical thin layer chromatography was carried out on the precoated Merck silica gel $60 \mathrm{~F}_{254}$ and iodine was used for development of compounds. IR was recorded on FTIR IR Affinity -1 Shimadzu spectrophotometer. CHNS analysis was recorded on Elementar Vario El-III. Dulbecco's Modified Eagle medium (DMEM), Fetal Bovine Serum (FBS) and phosphate buffer saline were procured from Invitrogen. Trypsin and antibiotic solutions were procured from Sigma-Aldrich.

\subsection{General procedure}

3.2.1 Synthesis of methyl 3,5-dimethoxybenzoate (2). The intermediate 2 was prepared as per reported method by Mc Nulty and Mcleod. ${ }^{18}$ In brief, 3,5-dihydroxy benzoic acid (6 $\mathrm{mmol}$ ) was taken in dry acetone. The mixture was stirred at $40{ }^{\circ} \mathrm{C}$ for $15 \mathrm{~min}$, to this $\mathrm{K}_{2} \mathrm{CO}_{3}(2.5 \mathrm{mmol})$ added and the mixture again stirred at $60{ }^{\circ} \mathrm{C}$ for $10 \mathrm{~min}$. Then dimethyl sulfate $(2.2 \mathrm{mmol}$ ) was added dropwise over a period of $30 \mathrm{~min}$ and the temperature was increased slowly to $80{ }^{\circ} \mathrm{C}$. The reaction mixture was allowed to reflux for $6 \mathrm{~h}$. The progress of the reaction was checked by TLC. After completion, reaction was allowed to cool to the room temperature and filtered through the Celite bed. The filtered mixture was concentrated to get crude product. The crude product was slowly poured on crushed ice with constant stirring to obtain solid. The solid obtained was filtered and dried to get methyl 3,5-dimethoxybenzoate in $92 \%$ yield.

3.2.2 Synthesis of methyl 2-acetyl-3,5-dimethoxybenzoate (3). The methyl 3,5-dimethoxybenzoate (5 mmol) was mixed with acetyl chloride $(25 \mathrm{mmol})$ and carbon disulfide $(2 \mathrm{ml})$ under dry $\mathrm{N}_{2}$ in ice bath. ${ }^{19}$ To this $\mathrm{AlCl}_{3}(15 \mathrm{mmol})$ was added under vigorous stirring. The reaction was allowed to stir for $15 \mathrm{~min}$. The progress of the reaction was monitored by TLC. After completion, the reaction was quenched with ice and extracted with ethyl acetate. The organic layer was separated, dried over sodium sulfate and concentrated to get a crude product, which was purified by the column chromatography (hexane-ethyl acetate, $70: 30$ ) to obtain methyl 2-acetyl-3,5dimethoxybenzoate in $52 \%$ yield.

3.2.3 Synthesis of methyl 2-acetyl-3,5-dihydroxybenzoate (4). Methyl 2-acetyl-3,5-dimethoxybenzoate (4 $\mathrm{mmol})$ was appended in chlorobenzene $(15 \mathrm{ml})$, to this $\mathrm{AlCl}_{3}(10 \mathrm{mmol})$ was added slowly at room temperature ${ }^{\mathbf{2 0}}$ and the reaction mixture was heated to reflux for $1 \mathrm{~h}$. The progress of the reaction was scrutinized by the TLC. After completion, the reaction was cooled to room temperature and hydrolysed using $1 \mathrm{~N} \mathrm{HCl}$. The reaction mixture was extracted with ethyl acetate. The organic layer was separated, dried over sodium sulfate and concentrated to obtain a crude product. The crude product was purified by the column chromatography (hexane-ethyl acetate, $80: 20$ ) to acquire clean methyl 2-acetyl-3,5-dihydroxybenzoate with $68 \%$ yield.

3.2.4 Synthesis of methyl 7-hydroxy-2-(4-methoxyphenyl)-4oxo-3,4-dihydro-2H-chromene-5-carboxylate (5). Methyl 2acetyl-3,5-dihydroxybenzoate $(4.7 \mathrm{mmol})$ in DMSO was mixed with anisaldehyde $(4.7 \mathrm{mmol}), \mathrm{I}_{2}(0.23 \mathrm{mmol})$ and pyrrolidine $(2.3 \mathrm{mmol})$ as per the procedure mentioned in the literature ${ }^{22}$ and heated at reflux temperature for $8 \mathrm{~h}$. The progress of the reaction was observed by the TLC. After completion, reaction was allowed to cool to the room temperature and quenched with water. The aqueous layer was extracted with ethyl acetate. The organic layer was separated, dried over sodium sulfate and concentrated to get a crude product, which was purified by the column chromatography (hexane-ethyl acetate, $50: 50$ ) and methyl 7-hydroxy-2-(4-methoxyphenyl)-4-oxo-3,4-dihydro-4Hchromene-5-carboxylate was achieved in $45 \%$ yield.

3.2.5 Synthesis of methyl 7-hydroxy-2-(4-methoxyphenyl)-4oxo-4H-chromene-5-carboxylate (6a). $\quad \mathrm{I}_{2} \quad\left(\begin{array}{lll}0.15 & \mathrm{mmol}) & \text { was }\end{array}\right.$ appended to methyl 7-hydroxy-2-(4-methoxyphenyl)-4-oxo-3,4dihydro-2H-1-benzopyran-5-carboxylate $(3 \mathrm{mmol})$ in DMSO (10 $\mathrm{ml}$ ) and refluxed for $1 \mathrm{~h}$. The progress of the reaction was observed by the TLC. After completion, reaction mixture was cooled to the room temperature and quenched with water. The aqueous layer was extracted with ethyl acetate. The organic layer was separated, dried over sodium sulfate and concentrated and a crude product obtained, which was purified by the column chromatography (hexane-ethyl acetate, $40: 60)$ and obtained methyl 7-hydroxy-2-(4-methoxyphenyl)-4-oxo-4H-chromene-5carboxylate in $60 \%$ yield.

Methyl 7-hydroxy-2-(4-methoxyphenyl)-4-oxo-4H-chromene-5carboxylate (6a). Mp: $226-228{ }^{\circ} \mathrm{C}$; IR $\left(\mathrm{KBr}, \mathrm{cm}^{-1}\right), 3446(\mathrm{OH})$, $1735(\mathrm{C}=\mathrm{O}), 1624(\mathrm{C}=\mathrm{O}) ;{ }^{1} \mathrm{H}$ NMR (400 MHz, DMSO-d $\left.{ }_{6}\right) \delta 3.81$ $\left(\mathrm{s}, 3 \mathrm{H}, \mathrm{OCH}_{3}\right), 3.86\left(\mathrm{~s}, 3 \mathrm{H}, \mathrm{OCH}_{3}\right), 6.79(\mathrm{~s}, 1 \mathrm{H}, 3-\mathrm{H}), 6.82(\mathrm{~d}, 1 \mathrm{H}$, $8-\mathrm{H}, J=1.6 \mathrm{~Hz}), 7.10(\mathrm{~d}, 1 \mathrm{H}, 6-\mathrm{H}, J=2 \mathrm{~Hz}), 7.12\left(\mathrm{~d}, 2 \mathrm{H}, 3^{\prime}, 5^{\prime}-\mathrm{H}, J\right.$ $=7.2 \mathrm{~Hz}), 8.04\left(\mathrm{~d}, 2 \mathrm{H}, 2^{\prime}, 6^{\prime}-\mathrm{H}, J=7.2 \mathrm{~Hz}\right), 11.14(\mathrm{~s}, 1 \mathrm{H}, \mathrm{OH}) ;{ }^{13} \mathrm{C}$ NMR, (100 MHz, DMSO-d $\left.{ }_{6}\right) \delta 52.86\left(\mathrm{OCH}_{3}\right) 55.97\left(\mathrm{C}-4^{\prime}, \mathrm{OCH}_{3}\right)$, 104.25 (C-8), 105.58 (C-3), 113.55 (C-10), 113.94 (C-6), 114.81 (C-3'), $114.98\left({\mathrm{C}-5^{\prime}}^{\prime}\right), 123.49\left(\mathrm{C}-1^{\prime}\right), 127.11\left(\mathrm{C}-6^{\prime}\right), 128.59\left(\mathrm{C}-2^{\prime}\right)$, 134.55 (C-5), 157.7 (C-9), 158.55 (C-4'), 162.39 (C-2), 162.54 (C-7), 169.19 (C-11), 175.68 (C-4); LCMS (ESI) $\mathrm{m} / \mathrm{z}$ calculated for $\mathrm{C}_{18} \mathrm{H}_{14} \mathrm{O}_{6}: 326.3$ and found 327.0; HRMS $m / z 327.0863[\mathrm{M}+1]^{+}$ elemental analysis calculated for $\mathrm{C}_{18} \mathrm{H}_{14} \mathrm{O}_{6}$ : C, 66.25, H, 4.32; found: C, 66.31, H, 4.28.

Methyl 7-hydroxy-2-(4-methylphenyl)-4-oxo-4H-chromene-5carboxylate (6b). Mp: $240-242{ }^{\circ} \mathrm{C}$; IR $\left(\mathrm{KBr}, \mathrm{cm}^{-1}\right), 3516(\mathrm{OH})$, $1737(\mathrm{C}=\mathrm{O}), 1627(\mathrm{C}=\mathrm{O}) ;{ }^{1} \mathrm{H}$ NMR (400 MHz, DMSO-d $\left.{ }_{6}\right) \delta 2.39$ $\left(\mathrm{s}, 3 \mathrm{H}, \mathrm{CH}_{3}\right), 3.81\left(\mathrm{~s}, 3 \mathrm{H}, \mathrm{OCH}_{3}\right), 6.83(\mathrm{~s}, 1 \mathrm{H}, 3-\mathrm{H}), 6.84\left(\mathrm{~s}, 1 \mathrm{H}, 8^{-}\right.$ $\mathrm{H}), 7.10$ (s, 1H, 6-H), 7.38 (d, 2H, $\left.J=8.0 \mathrm{~Hz}, 3^{\prime}, 5^{\prime}-\mathrm{H}\right), 7.95$ (d, 2H, $\left.J=8.0 \mathrm{~Hz}, 2^{\prime}, 6^{\prime}-\mathrm{H}\right), 11.18(\mathrm{~s}, 1 \mathrm{H}, \mathrm{OH}) ;{ }^{13} \mathrm{C} \mathrm{NMR},(100 \mathrm{MHz}$, DMSO-d 6 ) $\delta 21.51\left(\mathrm{CH}_{3}\right), 52.88\left(\mathrm{OCH}_{3}\right), 104.27(\mathrm{C}-8), 106.46(\mathrm{C}-$ 3), 113.43 (C-10), 113.68 (C-6), 126.68 (C-2', 6'), 128.55 (C-1'), $130.14\left(\mathrm{C}-3^{\prime}, 5^{\prime}\right), 130.25$ (C-4'), 134.58 (C-5), 142.42 (C-9), 157.78 (C-2), 162.49 (C-7) 169.14 (C-11), 175.76 (C-4); LCMS (ESI) m/z calculated for $\mathrm{C}_{18} \mathrm{H}_{14} \mathrm{O}_{5}: 310.3$ and found 311.0. Elemental 
analysis calculated for $\mathrm{C}_{18} \mathrm{H}_{14} \mathrm{O}_{5}$ : C, 69.66, H, 4.54; found: C, 69.61, H, 4.49.

Methyl 2-(3,4-dimethoxyphenyl)-7-hydroxy-4-oxo-4H-chromene5-carboxylate (6c). Mp: $233-236{ }^{\circ} \mathrm{C}$; IR $\left(\mathrm{KBr}, \mathrm{cm}^{-1}\right), 3444(\mathrm{OH})$, $1737(\mathrm{C}=\mathrm{O}), 1627(\mathrm{C}=\mathrm{O}) ;{ }^{1} \mathrm{H}$ NMR (400 MHz, DMSO-d 6$) \delta 3.78$ $\left(\mathrm{s}, 3 \mathrm{H}, \mathrm{OCH}_{3}\right), 3.81\left(\mathrm{~s}, 3 \mathrm{H}, \mathrm{OCH}_{3}\right), 3.85\left(\mathrm{~s}, 3 \mathrm{H}, \mathrm{OCH}_{3}\right), 6.79$ (s, $1 \mathrm{H}, 3-\mathrm{H}), 6.84(\mathrm{~s}, 1 \mathrm{H}, 8-\mathrm{H}), 7.13\left(\mathrm{~m}, 2 \mathrm{H}, 5^{\prime}-\mathrm{H}, 6-\mathrm{H}\right), 7.52$ (s, 1H, $2^{\prime}-$ $\mathrm{H}), 7.63$ (d, 1H, $\left.6^{\prime}-\mathrm{H}, J=8 \mathrm{~Hz}\right), 11.08$ (s, 1H, OH); ${ }^{13} \mathrm{C} \mathrm{NMR,} \mathrm{(100}$ $\left.\mathrm{MHz}, \mathrm{DMSO}-\mathrm{d}_{6}\right) \delta 52.87\left(\mathrm{OCH}_{3}\right), 56.17\left(\mathrm{OCH}_{3}\right), 56.32\left(\mathrm{OCH}_{3}\right)$, 104.34 (C-8), 105.89 (C-3), 109.83 (C-6'), 112.14 (C-5'), 113.39 (C10), 113.53 (C-6), $120.29\left(\mathrm{C}-1^{\prime}\right), 123.59\left(\mathrm{C}-2^{\prime}\right), 134.51(\mathrm{C}-5), 149.47$ (C-3'), 152.34 (C-4'), 157.74 (C-9), 162.36 (C-2), 162.48 (C-7), 169.19 (C-11), 175.74 (C-4); LCMS (ESI) $\mathrm{m} / \mathrm{z}$ calculated for $\mathrm{C}_{19} \mathrm{H}_{16} \mathrm{O}_{7}$ : 356.32 and found 357.0; elemental analysis calculated for $\mathrm{C}_{19} \mathrm{H}_{16} \mathrm{O}_{7}$ : C, 64.04, $\mathrm{H}, 4.52$; found: $\mathrm{C}, 64.16, \mathrm{H}, 4.59$.

Methyl 2-(4-chlorophenyl)-7-hydroxy-4-oxo-4H-chromene-5carboxylate (6d). Mp: $262-268{ }^{\circ} \mathrm{C}$; IR $\left(\mathrm{KBr}, \mathrm{cm}^{-1}\right), 3645(\mathrm{OH})$, $1714(\mathrm{C}=\mathrm{O}), 1697(\mathrm{C}=\mathrm{O}) ;{ }^{1} \mathrm{H}$ NMR (400 MHz, DMSO-d $\left.\mathrm{d}_{6}\right) \delta 3.78$ $\left(\mathrm{s}, 3 \mathrm{H}, \mathrm{OCH}_{3}\right), 6.80(\mathrm{~s}, 1 \mathrm{H}, 3-\mathrm{H}), 6.89(\mathrm{~s}, 1 \mathrm{H}, 8-\mathrm{H}), 7.08(\mathrm{~s}, 1 \mathrm{H}, 6-$ $\mathrm{H}), 7.60\left(\mathrm{~d}, 2 \mathrm{H}, 2^{\prime}, 6^{\prime}-\mathrm{H}, J=8.4 \mathrm{~Hz}\right), 8.07$ (d, 2H, 3', 5' $-\mathrm{H}, J=8.8$ $\mathrm{Hz}), 11.19$ (s, 1H, OH); ${ }^{13} \mathrm{C}$ NMR, (100 MHz, DMSO-d $\left.{ }_{6}\right) \delta 52.91$ $\left(\mathrm{OCH}_{3}\right), 104.32$ (C-8), 107.48 (C-3), 113.36 (C-10), 113.86 (C-6), $128.60\left(\mathrm{C}-2^{\prime}, 6^{\prime}\right), 129.62\left(\mathrm{C}-3^{\prime}, 5^{\prime}\right), 130.28\left(\mathrm{C}-1^{\prime}\right), 134.60(\mathrm{C}-5)$, 136.99 (C-9), 157.79 (C-4'), 161.24 (C-2), 162.63 (C-7), 169.06 (C-11), 175.75 (C-4); LCMS (ESI) $\mathrm{m} / z$ calculated for $\mathrm{C}_{17} \mathrm{H}_{11} \mathrm{ClO}_{5}$ : 330.71 and found 331.0; elemental analysis calculated for $\mathrm{C}_{17} \mathrm{H}_{11} \mathrm{ClO}_{5}$ : C, 61.73, H, 3.34; found: C, 61.67, H, 3.28.

Methyl 2-(4-bromophenyl)-7-hydroxy-4-oxo-4H-chromene-5carboxylate (6e). $\mathrm{Mp}: 275-27{ }^{\circ} \mathrm{C}$; IR $\left(\mathrm{KBr}, \mathrm{cm}^{-1}\right), 3564(\mathrm{OH})$, $1737(\mathrm{C}=\mathrm{O}), 1627(\mathrm{C}=\mathrm{O}) ;{ }^{1} \mathrm{H}$ NMR (400 MHz, DMSO-d 6 ) $\delta 3.78$ $\left(\mathrm{s}, 3 \mathrm{H}, \mathrm{OCH}_{3}\right), 6.81(\mathrm{~s}, 1 \mathrm{H}, 8-\mathrm{H}), 6.90(\mathrm{~s}, 1 \mathrm{H}, 6-\mathrm{H}), 7.07(\mathrm{~s}, 1 \mathrm{H}, 3-$ $\mathrm{H}), 7.75\left(\mathrm{~d}, 2 \mathrm{H}, 2^{\prime}, 6^{\prime}-\mathrm{H}, J=8 \mathrm{~Hz}\right), 8.0\left(\mathrm{~d}, 2 \mathrm{H}, 3^{\prime}, 5^{\prime}-\mathrm{H}, J=8 \mathrm{~Hz}\right)$, $11.18(\mathrm{~s}, 1 \mathrm{H}, \mathrm{OH}) ;{ }^{13} \mathrm{C} \mathrm{NMR},\left(100 \mathrm{MHz}, \mathrm{DMSO}_{6}\right) \delta 53.03$ $\left(\mathrm{OCH}_{3}\right) 104.38$ (C-8), 107.41 (C-3), 113.35 (C-10), 113.93 (C-6), $126.01\left(\mathrm{C}-2^{\prime}, \mathrm{C}-6^{\prime}\right), 128.78\left(\mathrm{C}-3^{\prime}, 5^{\prime}\right), 130.59\left(\mathrm{C}-1^{\prime}\right), 132.62$ (C-5), 134.62 (C-9), 157.84 (C-4'), 161.52 (C-2), 162.70 (C-7), 169.19 (C-11), 175.90 (C-4); LCMS (ESI) $m / z$ calculated for $\mathrm{C}_{17} \mathrm{H}_{11} \mathrm{BrO}_{5}$ : 375.17 and found $376.9,378.9$. Elemental analysis calculated for $\mathrm{C}_{17} \mathrm{H}_{11} \mathrm{BrO}_{5}$ : C, 54.42, H, 2.95; found: C, 54.48, H, 2.95.

Methyl 2-(2-fluorophenyl)-7-hydroxy-4-oxo-4H-chromene-5carboxylate (6f). Mp: $222-225{ }^{\circ} \mathrm{C}$; IR $\left(\mathrm{KBr}, \mathrm{cm}^{-1}\right), 3645(\mathrm{OH})$, $1732(\mathrm{C}=\mathrm{O}), 1697(\mathrm{C}=\mathrm{O}) ;{ }^{1} \mathrm{H}$ NMR (400 MHz, DMSO-d $\left.{ }_{6}\right) \delta 3.81$ (s, 3H, $\left.\mathrm{OCH}_{3}\right), 6.65(\mathrm{~s}, 1 \mathrm{H}, 3-\mathrm{H}), 6.86(\mathrm{~s}, 1 \mathrm{H}, 8-\mathrm{H}), 7.06$ (s, 1H, 6$\mathrm{H})$, 7.41-7.5 (m, 2H, 5'-H, 6'-H), 7.63-7.70 (m, 1H, 4'-H), 8.02$8.06\left(\mathrm{~m}, 1 \mathrm{H}, 3^{\prime}-\mathrm{H}\right), 11.22(\mathrm{~s}, 1 \mathrm{H}, \mathrm{OH}) ;{ }^{13} \mathrm{C} \mathrm{NMR,} \mathrm{(100} \mathrm{MHz,}$ $\left.\mathrm{DMSO}_{6}\right) \delta 52.81\left(\mathrm{OCH}_{3}\right), 104.15(\mathrm{C}-8), 110.07$ (C-6). $110.71(\mathrm{C}-$ 10), $116.12\left(\mathrm{C}-5^{\prime}\right), 116.30$ (C-3), $125.21\left(\mathrm{C}-3^{\prime}\right), 128.93\left(\mathrm{C}-1^{\prime}\right)$, 128.96 (C-6'), 131.36 (C-9), 136.50 (C-5), 159.11 (C-2'), 161.07 (C$4^{\prime}$ ), 163.43 (C-2), 164.45 (C-7), 169.39 (C-11), 185.83 (C-4); LCMS (ESI) $m / z$ calculated for $\mathrm{C}_{17} \mathrm{H}_{11} \mathrm{FO}_{5}$ : 314.26 and found 315.0. Elemental analysis calculated for $\mathrm{C}_{17} \mathrm{H}_{11} \mathrm{FO}_{5}$ : C, 64.96, $\mathrm{H}, 3.52$; found: C, 64.91, H, 3.56.

7-Hydroxy-2-(4-methoxyphenyl)-5-methyl-4-oxo-4H-chromene (6g). Mp: $245-249{ }^{\circ} \mathrm{C}$; IR ( $\left.\mathrm{KBr}, \mathrm{cm}^{-1}\right), 3566(\mathrm{OH}), 1704(\mathrm{C}=\mathrm{O})$; ${ }^{1} \mathrm{H}$ NMR (400 MHz, DMSO-d $\left.{ }_{6}\right) \delta 2.68\left(\mathrm{~s}, 3 \mathrm{H}, \mathrm{CH}_{3}\right), 3.83(\mathrm{~s}, 3 \mathrm{H}$, $\left.\mathrm{OCH}_{3}\right), 6.63(\mathrm{~s}, 1 \mathrm{H}, 3-\mathrm{H}), 6.67(\mathrm{~s}, 1 \mathrm{H}, 8-\mathrm{H}), 6.81(\mathrm{~s}, 1 \mathrm{H}, 6-\mathrm{H}), 7.08$ $\left(\mathrm{d}, 2 \mathrm{H}, 2^{\prime}, 6^{\prime}-\mathrm{H}, J=8.4 \mathrm{~Hz}\right), 7.97\left(\mathrm{~d}, 2 \mathrm{H}, 3^{\prime}, 5^{\prime}-\mathrm{H}, J=8.8 \mathrm{~Hz}\right), 10.59$ (s, 1H, OH); ${ }^{13} \mathrm{C}$ NMR, (100 MHz, DMSO-d 6 ) $\delta 22.92\left(\mathrm{CH}_{3}\right), 55.96$ $\left(\mathrm{C}-4^{\prime}, \mathrm{OCH}_{3}\right), 101.38$ (C-8), 106.82 (C-3), 114.95 (C-3', 5'), 117.19 (C-6), 123.73 (C-1'), 128.27 (C-2', 6'), 128.56 (C-10), 141.90 (C-5), 159.32 (C-9), 160.71 (C-4'), 161.57 (C-2), 162.26 (C-7) 178.91 (C4); LCMS (ESI) $\mathrm{m} / z$ calculated for $\mathrm{C}_{17} \mathrm{H}_{14} \mathrm{O}_{4}: 282.29$ and found 283.0. Elemental analysis calculated for $\mathrm{C}_{17} \mathrm{H}_{14} \mathrm{O}_{4}$ : C, 72.32, $\mathrm{H}$, 4.99; found: C, 72.36, H, 4.93.

7-Hydroxy-2-(4-methylphenyl)-5-methyl-4-oxo-4H-chromene (6h). Mp: $252-255^{\circ} \mathrm{C}$; IR ( $\left.\mathrm{KBr}, \mathrm{cm}^{-1}\right), 3565(\mathrm{OH}), 1710(\mathrm{C}=\mathrm{O})$; ${ }^{1} \mathrm{H}$ NMR (400 MHz, DMSO-d $\left.{ }_{6}\right) \delta 2.38\left(\mathrm{~s}, 3 \mathrm{H}, \mathrm{CH}_{3}\right), 2.69(\mathrm{~s}, 3 \mathrm{H}$, $\mathrm{CH}_{3}$ ), 6.65 (s, 1H, 3-H), $6.72(\mathrm{~s}, 1 \mathrm{H}, 8-\mathrm{H}), 6.82(\mathrm{~s}, 1 \mathrm{H}, 6-\mathrm{H}), 7.36$ $\left(\mathrm{d}, 2 \mathrm{H}, 3^{\prime}, 5^{\prime}-\mathrm{H}, J=8.4 \mathrm{~Hz}\right), 7.92\left(\mathrm{~d}, 2 \mathrm{H}, 2^{\prime}, 6^{\prime}-\mathrm{H}, J=7.6 \mathrm{~Hz}\right), 10.62$ (s, 1H, OH); ${ }^{13} \mathrm{C}$ NMR, (100 MHz, DMSO-d 6$) \delta 21.54\left(\mathrm{CH}_{3}\right), 22.92$ $\left(\mathrm{CH}_{3}\right), 101.40$ (C-8), 107.65 (C-3), $115.16\left(\mathrm{C}-1^{\prime}\right), 117.27$ (C-6), $126.41\left(\mathrm{C}-3^{\prime}, \mathrm{C}^{\prime} 5^{\prime}\right), 128.76$ (C-10), 130.12 (C-2', C-6'), 141.96 (C4', C-5), 159.37 (C-9), 160.78 (C-2), 161.67 (C-7), 178.94 (C-4); LCMS (ESI) $m / z$ calculated for $\mathrm{C}_{17} \mathrm{H}_{14} \mathrm{O}_{3}: 266.29$ and found 267.0. Elemental analysis calculated for $\mathrm{C}_{17} \mathrm{H}_{14} \mathrm{O}_{3}$ : C, 76.67, $\mathrm{H}$, 5.29; found: C, 76.62, H, 5.26.

2-(2-Fluorophenyl)-7-hydroxy-5-methyl-4-oxo-4H-chromene (6i). Mp: $252-255{ }^{\circ} \mathrm{C}$; IR (KBr, cm $\left.{ }^{-1}\right), 3564(\mathrm{OH}), 1714(\mathrm{C}=\mathrm{O}) ;{ }^{1} \mathrm{H}$ NMR (400 MHz, DMSO-d $\left.{ }_{6}\right) \delta 2.69\left(\mathrm{~s}, 3 \mathrm{H}, \mathrm{CH}_{3}\right), 6.55(\mathrm{~s}, 1 \mathrm{H}, 3-\mathrm{H})$, 6.67 (s, 1H, 6-H), 6.78 (s, 1H, 8-H), 7.41-7.48 (m, 2H, 5', 6'-H), 7.62-7.63 (m, 1H, 4'-H), 7.98-8.0 (m, 1H, 3'-H), $10.71(\mathrm{~s}, 1 \mathrm{H}$, $\mathrm{OH}) .{ }^{13} \mathrm{C}$ NMR, (100 MHz, DMSO-d $\left.)_{6}\right) 22.90\left(\mathrm{CH}_{3}\right), 101.34(\mathrm{C}-8)$, $112.91\left(\mathrm{C}-6^{\prime}\right), 113.01\left(\mathrm{C}-5^{\prime}\right), 114.96\left(\mathrm{C}-4^{\prime}\right), 117.24$ (C-6), 117.47 (C3), 125.71 (C-1'), $129.78\left(\mathrm{C}-3^{\prime}\right), 133.73\left(\mathrm{C}-2^{\prime}\right), 133.82(\mathrm{C}-10)$, 142.13 (C-5), 156.58 (C-9), 159.54 (C-2), 161.92 (C-7), 178.58 (C4); LCMS (ESI) $\mathrm{m} / \mathrm{z}$ calculated for $\mathrm{C}_{16} \mathrm{H}_{11} \mathrm{FO}_{3}: 270.25$ and found 271.0. Elemental analysis calculated for $\mathrm{C}_{16} \mathrm{H}_{11} \mathrm{FO}_{3}: \mathrm{C}$, 71.10, H, 4.09; found: C, 71.16, H, 4.17.

2-(3,4-Dimethoxylphenyl)-7-hydroxy-5-methyl-4-oxo-4H-chromene (6j). Mp: 231-234 ${ }^{\circ} \mathrm{C}$; IR ( $\left.\mathrm{KBr}, \mathrm{cm}^{-1}\right), 3564(\mathrm{OH}), 1704(\mathrm{C}=$ O); ${ }^{1} \mathrm{HMR}\left(400 \mathrm{MHz}, \mathrm{DMSO}-\mathrm{d}_{6}\right) \delta 2.69\left(\mathrm{~s}, 3 \mathrm{H}, \mathrm{CH}_{3}\right), 3.86(\mathrm{~s}, 3 \mathrm{H}$, $\left.\mathrm{OCH}_{3}\right), 3.90\left(\mathrm{~s}, 3 \mathrm{H}, \mathrm{OCH}_{3}\right), 6.76(\mathrm{~s}, 1 \mathrm{H}, 3-\mathrm{H}), 6.79(\mathrm{~s}, 1 \mathrm{H}, 8-\mathrm{H})$, 6.91 (d, 1H, 6-H), 7.13 (d, 1H, 6'- H, $J=7.2 \mathrm{~Hz}), 7.17$ (d, 1H, 2'-H, $7.2 \mathrm{~Hz}$ ), 7.77 (d, $\left.1 \mathrm{H}, 5^{\prime}-\mathrm{H}, J=7.2 \mathrm{~Hz}\right), 10.60$ (s, $\left.1 \mathrm{H}, \mathrm{OH}\right) .{ }^{13} \mathrm{C}$ NMR, (100 MHz, DMSO-d $\left.)_{6}\right) 22.90\left(\mathrm{CH}_{3}\right) 58.90\left(\mathrm{OCH}_{3}\right), 59.30$ $\left(\mathrm{OCH}_{3}\right), 101.33$ (C-8), 104.20 (C-3), 110.30 (C-6), $113.35\left(\mathrm{C}-1^{\prime}\right)$, 114.27 (C-10), 116.57 (C-6'), 120.50 (C-2'), 121.86 (C-5'), 141.86 (C-5), 149.83 (C-3'), 153.23 (C-4'), 159.30 (C-9), 160.80 (C-2), 162.55 (C-7), 178.90 (C-4); LCMS (ESI) $\mathrm{m} / \mathrm{z}$ calculated for $\mathrm{C}_{18} \mathrm{H}_{16} \mathrm{O}_{5}$ : 312.31 and found 313.0. Elemental analysis calculated for $\mathrm{C}_{18} \mathrm{H}_{16} \mathrm{O}_{5}$ : C, 69.21, $\mathrm{H}, 5.15$; found: $\mathrm{C}, 69.17, \mathrm{H}, \mathbf{5 . 1 1}$.

\subsection{Biology}

3.3.1 Cell lines and culture. Breast cancer MCF-7 and normal NIH3T3 cell lines were obtained from National Center for Cell Science, Pune, India. All cell lines were cultured in a humidified atmosphere of $5 \% \mathrm{CO}_{2}$ in DMEM at $37{ }^{\circ} \mathrm{C}$, supplemented with $10 \% \mathrm{FBS}$, penicillin $\left(100 \mu \mathrm{g} \mathrm{ml}{ }^{-1}\right)$ and streptomycin $\left(100 \mu \mathrm{g} \mathrm{ml}^{-1}\right)$.

3.3.2 MTT assay for cytotoxicity against MCF-7 and NIH3T3 cells. MCF-7 and NIH3T3 cells were grown in DMEM media containing $10 \%$ FBS. The effect of rugosaflavonoid derivatives on the growth of MCF-7 cells (breast cancer cell lines) and 
NIH3T3 cells was examined using the MTT assay. Cells were subcultured in 96-well plates at a density of $2.5 \times 10^{3}$ cells per well without test samples for $24 \mathrm{~h}$ in a final volume of $150 \mu \mathrm{l}$. After $24 \mathrm{~h}$, cells were treated with four different concentrations test specimens $(5,10,15$ and $20 \mu \mathrm{M}$ in plain DMEM) in triplicates and kept for $24 \mathrm{~h}$ in the $\mathrm{CO}_{2}$ incubator. Next day, treatment media was removed and $20 \mu \mathrm{l}$ of MTT (1.5 $\mathrm{mg} \mathrm{ml}^{-1}$ in PBS) was added to the fresh medium. After three hours' of incubation at $37{ }^{\circ} \mathrm{C}$ in $\mathrm{CO}_{2}$ incubator, $180 \mu \mathrm{l}$ DMSO was added to the each well and plates were agitated for $1 \mathrm{~min}$. Spectrophotometric absorbance at $570 \mathrm{~nm}$ was measured. The percentage of viability was calculated as per the following formula: (viable cells $) \%=($ OD of drug-treated sample/OD of untreated sample) $\times 100$. Quercetin was used as the standard.

\subsection{Molecular docking studies}

The molecular modelling studies were carried out on Windows 7 64-bit operating system using Maestro 11.2 software. The GLIDE docking application of Maestro 11.2 software was used to calculate GScore, which is based on an empirical scoring function and deploy a combination of several parameters. GScore (docking score) was calculated in $\mathrm{kcal} \mathrm{mol}^{-1}$ and it included ligand-protein interaction energies, hydrophobic interactions, hydrogen bonds, internal energy, $\pi-\pi$ stacking interactions, root mean square deviation (RMSD) and desolvation. The X-ray crystallographic structure of erlotinib cocrystallized with EGFR was obtained from the protein data bank (PDB ID: 1M17). The ATP binding site of EGFR was prepared for docking studies in which erlotinib was removed from the active site, hydrogen atoms were added to the structure with their standard geometry. Active sites were observed from the sequence analysis and software run and it was used in predicting interactions at the active site between the selected compounds $6 \mathbf{f}$ and quercetin with EGFR. The 2D structures of the docked compounds were generated, transformed to $3 \mathrm{D}$, protonated, and energy was minimized by using Ligprep application. Grid generation and ligand docking was performed to obtain ligand interaction diagram with 1M17 EGFR and docking score. Receptor-ligand interaction images were obtained from discovery studio client version.

\section{Conclusion}

In summary, we successfully completed a simple and convenient 5 steps synthesis for a naturally occurring rugosaflavonoid (6a) with better yield and evaluated its cytotoxicity against breast cancer cell lines. Molecular docking score of its derivatives with EGFR (1M17) showed that it interacted with active site pocket of 1M17. Some of the synthetic derivatives showed better dose dependent activity against MCF7 than the natural molecule rugosaflavonoid and were found to be non toxic to NIH3T3 cell lines at lower concentration. Though flavonoids are known from the years for their bioactive potential but there is still scope in modifications of natural analogs, which may provide us the lead molecules.

\section{Conflict of interest}

There is no conflict of interest among the authors.

\section{Acknowledgements}

Authors are really thankful to $\mathrm{Hu}$ et al. for the isolation and characterization of rugosaflavonoid because of his team work we are able to develop synthetic route for naturally occurring compound (6a). We acknowledge the unconditional support of Mr Vinod Devaraji to understand Maestro 11.2 software to perform the molecular docking studies. Authors are also thankful to Agharkar Research Institute, Pune, India, for providing financial support and infrastructure.

\section{Notes and references}

1 R. Siegel, J. Ma, Z. Zou and A. Jemal, Ca-Cancer J. Clin., 2014, 64, 9-29.

2 C. Andreetta, A. M. Minisini, M. Miscoria and F. Puglisi, Crit. Rev. Oncol. Hematol., 2010, 76, 99-111.

3 A. Jemal, R. Siegel, J. Xu and E. Ward, Ca-Cancer J. Clin., 2010, 60, 277-300.

4 N. G. Anderson, T. Ahmad, K. Chan, R. Dobson and N. G. Bundred, Int. J. Cancer Res., 2001, 94, 774-782.

5 A. Arora and E. M. Scholar, J. Pharmacol. Exp. Ther., 2005, 315, 971-979.

6 D. J. Newman and G. M. Cragg, J. Nat. Prod., 2007, 70, 461477.

7 A. Gaspar, M. J. Matos, J. Garrido, A. Uriarte and F. Borges, Chem. Rev., 2014, 114, 4960-4992.

8 A. K. Verma and R. Pratap, Nat. Prod. Rep., 2010, 27, 15711593.

9 S. M. Gault and P. M. Synge, The Dictionary of Roses in Colour, Ebury Press, London, 1971.

10 L. Putian and Y. Jiang, Flora of China, Chinese Science Press, Beijing, 1977.

11 S. Ochir, B. J. Park, M. Nishizawa, T. Kanazawa, M. Funaki and T. J. Yamagishi, J. Nat. Med., 2010, 64, 383-387.

12 Y. Hashidoko, Phytochemistry, 1996, 43, 535-549.

13 Y. Hashidoko, S. Tahara and J. Mizutani, Phytochemistry, 1993, 32, 387-390.

14 H. J. An, I. T. Kim, H. J. Park, H. M. Kim, J. H. Choi and K. T. Lee, Int. Immunopharmacol., 2011, 11, 504-510.

15 Z. P. Xiao, H. K. Wu, T. Wu, H. Shi, B. Hang and H. A. Aisa, Chem. Nat. Compd., 2006, 42, 736-737.

16 X. Gao, L. Yang, L. Shu, Y. Shen, Y. Zhang and Q. Hu, Heterocycles, 2012, 85, 1925-1931.

17 Q. F. Hu, B. Zhou, J. M. Huang, Z. Y. Jiang, X. Z. Huang, L. Y. Yang, X. M. Gao, G. Y. Yang and C. T. Che, J. Nat. Prod., 2013, 76, 1866-1871.

18 J. McNulty and D. Mcleod, Tetrahedron Lett., 2013, 54, 63036306.

19 J. Maresh, J. Zhang, Y. L. Tzeng, N. A. Goodman and D. G. Lynn, Bioorg. Med. Chem. Lett., 2007, 17, 3281-3286.

20 J. Johann, PCT Int. Appl., 2010, 2010022953. 
21 G. Bringmann, T. F. Noll, T. Gulder, M. Dreyer, M. Grune and D. Moskau, J. Org. Chem., 2007, 72, 3247-3252.

22 M. M. Naik, S. G. Tilve and V. P. Kamat, Tetrahedron Lett., 2014, 55, 3340-3343.

23 J. M. Useros and J. G. Foncillas, Oral Oncol., 2015, 51, 423430.
24 J. Wang, J. M. Yu, S. W. Jing, Y. Guo, Y. J. Wu, N. Li, W. P. Jiao, L. Wang and Y. J. Zhang, Asian Pac. J. Cancer Prev., 2014, 15, 5889-5893.

25 J. Stamos, M. X. Sliwkowski and C. Eigenbrot, J. Biol. Chem., 2002, 277, 46265-46272.

26 P. Singh and F. Bast, Med. Chem. Res., 2014, 23, 5074-5085. 